August 2007

\title{
The Armenian Genocide and an Updated Denial Initiative: A Review Essay
}

Joseph A. Kéchichian

Follow this and additional works at: https://digitalcommons.usf.edu/gsp

\section{Recommended Citation}

Kéchichian, Joseph A. (2007) "The Armenian Genocide and an Updated Denial Initiative: A Review Essay," Genocide Studies and Prevention: An International Journal: Vol. 2: Iss. 2: Article 6.

Available at: https://digitalcommons.usf.edu/gsp/vol2/iss2/6

This Articles is brought to you for free and open access by the Open Access Journals at Digital Commons @ University of South Florida. It has been accepted for inclusion in Genocide Studies and Prevention: An International Journal by an authorized editor of Digital Commons @ University of South Florida. For more information, please contact digitalcommons@usf.edu. 


\title{
The Armenian Genocide and an Updated Denial Initiative: A Review Essay
}

\author{
Joseph A Kéchichian
}

\section{Guenter Lewy. The Armenian Massacres in Ottoman Turkey: A Disputed Genocide. Salt Lake City: The University of Utah Press, 2005. Pp. 384, cloth. \$24.95 US.}

When on 12 October 2006 the French National Assembly approved a bill that made it a crime to deny the mass killings of Armenians in Turkey around the turn of the twentieth century, Turkish leaders lamented the decision as a great disappointment, while several European officials insisted that it was not for the law to write history. That task, however, is compromised when leading historians deny, in Jacques Chirac's memorable words, a country's "dramas and errors."1 Because experts are lured to power, sometimes at the expense of their integrity, it behooves those searching for the truth to redouble their efforts. Therefore, the genuine need to identify and correct assertions made by those who wish to deny historical facts is a duty both to history and to the truth itself. Guenter Lewy, an emeritus professor of political science at the University of Massachusetts-Amherst, is the latest researcher attempting to deny the Armenian Genocide. ${ }^{2}$

Indeed, the inordinate nature of Lewy's resort to political leverage is such as to render the need for a critical review of this agenda-laden tome even more pressing. As Lewy has declared that "a book [must] be judged by its content and not by the motive of its author,"3 this review will attempt such an endeavor. Lewy opines that "most Armenians... do not know Turkish" (xi); according to him, therefore, few Armenians may be competent to write on the topic of the Armenian Genocide or to offer critiques of books on the subject. In fact, however, not only do many Armenians know Turkish, some are fluent in the language-including this reviewer. ${ }^{4}$

\section{The Relocation Assertion}

Lewy systematic uses and emphasizes the term "relocation" throughout his book; this prejudicial stance is striking, and the theme of relocation truly dominates the text. According to Lewy, Turkish authorities had no intention of liquidating the Armenian population but were merely trying to deport and resettle that population; their blunders and failures in the process caused massive but unintended casualties. To foster this perspective, Lewy relies on several techniques, including pronounced selectivity of data, deflection, distortion, and occasional falsification.

We are told, for example, that the American Associated Press correspondent George Abel Schreiner explained the fate of the Armenians as merely the result of "Turkish ineptness, more than intentional brutality" (qtd. 254); Schreiner asks us to believe that it was mere clumsiness that "was responsible for the hardships the Armenians were subjected to" (qtd. 254). ${ }^{5}$ In a widely read volume published in 1918 , however, and based on diary entries written immediately after particular events, Schreiner writes, "the Armenians are going through hell again...[because] the 
deportations... [presented a] shocking phase of barbarity..."6 Schreiner, who had interviewed both Mehmet Talât Pasha and Ismail Enver Pasha, the two principal architects of the Armenian Genocide, preserved his unedited diaries. Of course, in writing "again," his point of reference is actually the 1909 Adana massacres, which formed the prelude to the 1915 genocide. Schreiner's rich text, based on first-hand observations, since he maintained that he personally witnessed horrible acts that he denounced as "repulsive, loathsome, [that] must cause us to consider whether or not the Turk has a right to rule others." He perceptively asks whether "a Government that tolerates this [may be] so low, contemptible, a thing that nothing whatever can be said in its favor."7

Lewy further quotes Dr. Leopold Gustav Alexander von Hoesch, who compiled German ambassador Wolff-Metternich's seventy-two-page report of 18 September 1916, which dealt with the Armenian deportations and massacres, as follows: "The authorities...had been unprepared for the deportations and therefore had failed to provide food and protection for the exiles" (254). Lewy implies that Constantinople did not approve of any hardships and that victims paid the price of disorder. Yet, in the same report, the German expert categorically declares that there was no Armenian "general uprising." "Apart from that in Van, Von Hoesch characterized the three other uprisings as acts of self-defense in the face of imminent mass deportations. ${ }^{9}$ What is even more significant is that the German expert granted the reasonableness of this right of self-defense. ${ }^{10}$ Remarkably, his report reveals that, long before the Turkish defeat of Sarikamis and the Van uprisings, anti-Armenian acts were occurring in Erzurum in December $1914 .^{11}$

The selective quotation continues with a statement attributed to Dr. Mustafa Reşid, the governor of Diyarbekir province and one of the most wanton organizers of the Armenian Genocide, as saying that "the disorganization of the State authorities was so pronounced that an orderly deportation became impossible" (254). Yet, on several occasions, this same governor not only conceded his role in having tens of thousands of Armenians massacred in his province but openly bragged about it. Reşid's deranged rationale was that Armenians were "microbes infesting" the fatherland (musallat mikrob) and that he, as a physician, found it necessary to "eradicate sick people."12

Lewy's text is peppered with such gems. For example, when he discusses the April 1915 Armenian uprising in Van, Lewy writes that "the Armenians of Van ... went on the offensive" (96). This kernel is based on the statements of Major Rafael de Nogales, a Venezuelan soldier of fortune who volunteered his services to the Turkish military. Yet, in his massive tome, de Nogales actually writes,

The Armenians had attacked the town [Van]. Immediately I mounted my horse ... went to see what was happening. Judge of my amazement to discover that the aggressors had not been the Armenians after all, but the civil authorities themselves... Supported by the Kurds and the rabble of the vicinity, they were attacking and sacking the Armenian quarter. $^{13}$

Obviously, these are serious discrepancies that cannot easily be dismissed. This particular episode was well documented by none other that Ibrahim Arvas, the former governor general of Van. In his memoirs, Arvas admits that the authorities, while denouncing Armenians, "underhandedly were inciting the people against the [same] Armenians, only to annihilate [itlaf] them at the end."14

To further buttress his content that the Turkish intention was to relocate the Armenians, Lewy expresses doubts about the reality of the drowning operations in 
the Black Sea through which a significant portion of the Armenian population of Trabzon province perished (181-82). It might be useful, once again, to refer to a Turkish parliamentarian representing that province, who stunned his colleagues with an inordinate disclosure. In fact, Hafez Mehmet, a lawyer by profession, testified and proclaimed to the Chamber of Deputies immediately after the war that he had personally witnessed drowning operations, in the port city of Ordu on the Black Sea, whereby Armenian children and women were loaded unto large barges and taken out to sea to be drowned. ${ }^{15}$ This particular question was addressed by the Turkish general Mehmet Vehip Pasha, wartime commander-in-chief of the Third Army, who further testified that "thousands of Armenians were also burned alive in haylofts."16

\section{From Relocation to Distortion}

Continuing, Lewy again cites "relocation" (155) and the problems associated with it, such as transportation, as the source of the peril of hundreds of thousands of Armenians. What we must accept is the incredible twist of misdirection ignoring the key problem, namely the ultimate destination of the deportees: the desolate and barren deserts of Mesopotamia. None other than the Turkish general Ali Fuad Erden, chief of staff of Cemal Pasha's Fourth Army, headquartered in that very same region, concedes the lethal purpose of this governmental measure: "There was neither preparation nor organization to shelter the hundreds of thousands of the deportees." 17 Ahmed Refik Altinay, another contemporary Turkish authority who has referred to these masses of Armenian deportees as being "driven to blazing deserts, to hunger, misery and death," holds a similar view. ${ }^{18}$ Following extensive research, Taner Akçam states that nowhere at their destination in the deserts "were there any requisite arrangements" for resettling or relocating the remnants of the Armenian deportees; this fact alone "is sufficient proof of the existence of this plan of annihilation."19 This fact was so well known that, on 16 July 1915, Hans Freiherr von Wangenheim, the Turkophile German ambassador to Turkey, felt constrained to warn Berlin that the Turkish ally was "bent on destroying the Armenians by relocating them in barren regions." For dubious reasons, Lewy ignores this important declaration as well. ${ }^{20}$

In fact, in his drive to question anything that substantiates the genocidal nature of the Armenian experience, Lewy ventures into the domain of legal squabbles to buttress his argumentation, even if he ends up more confused. He repeatedly invokes the procedures of the Nuremberg Tribunal $(72,80)$, especially with respect to documentary evidence, precisely to dismiss the findings of the post-war Turkish Military Tribunal as devoid of any value. For Lewy, Nuremberg is preferred as a criterion to invalidate Istanbul, especially with respect to the production and attestation of documents. One can easily identify a few misconceptions at work in this rationalization. First, the Nuremberg Tribunal was not only an international body but an instrument of military occupation; it therefore operated on standards at variance with those of the Turkish Military Tribunal in Istanbul. Second, the concept of "due process," as generally understood, was deliberately circumvented at Nuremberg, notwithstanding Lewy's assertions to the contrary. Indeed, article 19 of the Nuremberg Charter stipulated that

the Tribunal shall not be bound by technical rules of evidence. [Rather,] it shall adopt and apply to the greatest possible extent expeditious and non-technical procedure and shall admit any evidence which it deems to have probative value. ${ }^{21}$

Remarkably, although the Turkish Military Tribunal was a national rather than an international body, and although it operated as a national military court under the provisions of martial law, it embodied the very same stipulations contained in the 
above-cited art. 19 of the Nuremberg Charter. Moreover, in legal terminology, "probative" evidence is that which has the effect of proof, tends to prove, or actually proves, and is hence theoretically capable of producing conviction of, the main thingnamely, truth. Even though this was not required, the sessions of the Turkish court martial were conducted publicly, and defense counsel were allowed to present their cases, as is amply documented by the opening statements made during the first session of the major trials. Several defense lawyers, led by Celaleddin Arif, president of the Turkish Bar Association, took more than an hour to present their cases. ${ }^{22}$ Lewy further ignores a basic fact when he contrasts and deprecates the Turkish court martial with "Western standards of due process" (79). Perhaps he excludes France from the West; the fact is that Ottoman penal codes and the Ottoman Code of Criminal Procedures are almost entirely modeled after their French counterparts. ${ }^{23}$ Consequently, there is no room for "cross-examination," since French criminal law does not call for it. Furthermore, the state of siege then obtaining in Istanbul precluded recourse to standard rights and guarantees. As art. 2 of the Annex to the Temporary Law on the State of Siege provides, "While the State of Siege remains in force, Constitutional Laws and other Laws, and administrative rules are temporarily suspended." Article 3, on the other hand, provides that "the functions of Cabinet Council [shall] transfer to military authorities."24

Perhaps the most outlandish and patently pro-Turkish partisan claim in the entire book is Lewy's declaration that "no authentic documentary evidence exists to prove the culpability of the central government of Turkey for the massacres of 1915-16" (250). In other words, the systematic and brutal dislocation and deportation of hundreds of thousands of the victim population culminated by sheer accident in the violent extirpation of the bulk of that population. Readers are asked to believe that the central government, which had acquired overwhelming authority and power, miraculously became so helpless as to lose control over the arrangements of the deportation processes because of the exigencies of war. This is akin to believing that the Nazi government in Berlin had similarly lost control over the network of administrative personnel in charge of several concentration camps, thereby inadvertently allowing the systematic extermination of the millions of victims involved! Furthermore, Lewy asserts that since no "authentic documents" showing explicit orders for extermination are at hand, the victims must have perished for some other reason! As Hikmet Yusuf Bayur, the late dean of Turkish historians, maintained, "the most important cabinet decisions were secretly made by two or three people, [so] it is only natural that they will not show up in the transcripts of the Cabinet Council." ${ }^{25}$ Lewy conveniently ignores the fact that unlike the Nazis, who were obsessed with recordkeeping, the Young Turk perpetrators avoided keeping such records, as well as the fact that, shortly before their collective escape to Germany on 1-2 November 1918, they destroyed as many of the surviving documents as they could. In any event, a clarification that is sorely missing from Lewy's tome may provide the linkage to the next item to be discussed: the fact that the so-called central government of Turkey was one and the same entity as the Central Committee of the Young Turk movement, the Ittihat ve Terakki Partisi, or Committee of Union and Progress (CUP).

\section{The Gargantuan Mystery of the CUP}

The failure to identify the CUP's Central Committee as the supreme executive authority and the affiliated Tekilat-ı Mahsusa, or Special Organization (SO), as its lethal anti-Armenian instrument is truly mind-boggling. In fact, the linkage 
was authoritatively established by Mehmet Vehip, commander-in-chief of the Turkish Third Army, whose command zone encompassed the seven eastern and central provinces and, thus, the bulk of the Armenian population of Turkey. In his famous 5 December 1918 testimony, prepared upon the request of the Turkish Military Tribunal, Vehip clearly stated that governmental authorities (rüesayi hükümet) meekly and obediently submitted to the dictates of the CUP's Central Committee in the matter of "Armenian deportations and massacres [tehcir ve taktil]." Moving one step further, this vaunted Turkish officer bluntly confirmed the fact that CUP-directed operations of mass murder were carried out according to "a resolute plan [mukarer bir plan]," as well as with "definite prior deliberation [mutlak bir kasd tahtinda]"-in other words, with premeditation. ${ }^{26}$ Moreover, General Vehip exposed for the first time the role of the numerous convicts who were organized and enlisted by SO chief Dr. Bahaeddin Şakir; he described them as "gallows birds" and "butchers of human beings [insan kasaplari]."

This last point, one of the foremost features of the Armenian Genocide, is often overlooked but must not be. At the implementation level of the deportations, thousands of convicts were employed to carry out the merciless and wanton massacres, which engendered further hatred against the crime of organized mass murder. By denying this paramount fact, Lewy is either exhibiting total ignorance or indulging in unscrupulous distortion, if not falsification. The statement "there is no evidence anywhere that this or any other S.O. detachment was diverted to duty involving the Armenian deportations" (85) summarizes his position. Such a view is questionable and, in fact, fully rejected by a series of Turkish testimonies involving both primary and secondary sources. To plunge into this kind of research without a command of the Turkish language, relying on others whose identities are not divulged, is full of liabilities and risks, even inviting suspicions of intent and an agenda. What follows, by way of rebuttal of several specific falsifications, may convince Lewy and his supporters of these risks and avoid further confusion and obfuscation.

In his critical monograph Belgelerle Teskiläti Mahsusa, Ergun Hiçyilmaz declares that the SO was created to curb the domestic separatist movements that were imperiling the Ottoman Empire. ${ }^{27}$ Likewise, Suat Parlar, in Osmanlıdan Günümüze Gizli Devlet, confirms that "the SO was an Islamist and Turkist outfit that played an important role in unleashing terror against the Armenians and in liquidating the opposition." ${ }^{28}$ Ihsan Bïrinci, an expert on the SO, describes it as an outfit pursuing two principal goals, one of which was to safeguard "the Turkish race" through "the deportation of the Armenians." 29 For his part, Ahmet Refik Altinay, a professor at Istanbul University and a wartime official who dealt with Armenian deportations at Eskişehir, wrote that "the brigands of the SO committed the worst atrocities against the Armenians." 30 In addition to these corroborating statements, Galib Vardar, an actual SO chief in charge of logistics and organization, conceded that the SO was created to deal with "external as well as internal" problems. ${ }^{31}$ Another eminent Turkish political scientist, Tarik Zafer Tunaya, declares that the SO was composed in part of "convicts" and that Interior Minister Talât, chief organizer of the Armenian Genocide, was a partner in its creation and in formulating its missions. ${ }^{32}$ Sevket Süreyya Aydemir, the author of multiple volumes on the CUP and on CUP leader Enver Pasha, identifies the SO as a "secret and irresponsible" organization that was "involved in the Armenian deportations." 33 Celal Bayar, a Turkish statesman and longtime president of the Turkish Republic, quoting SO leader Esref Kusçubasi, wrote that one of the SO's functions was "the liquidation [tasfiye] of non-Turkish population 
blocs in Turkey."34 A final item on this brief list might refer to the verdict of a Turkish author, Doğan Avcioğlu, known to have had access to some of the innermost secrets of the CUP. In the third massive volume of his series on Turkish history, he reveals that the Central Committee of the CUP and Enver Pasha held a series of secret meetings at which it was decided to "liquidate" (tasfiye) the "Christian elements," for which purpose young and trusted staff officers were invited to Istanbul to map out the requisite plans. ${ }^{35}$ Without mincing words, Avcığlu declares that "the ultimate goal of the Armenian deportations was to radically solve [temelinde çözme] the Armenian Question through the engagement of the SO. It was Dr. Bahaeddin Şakir who pushed this plan, championing it at the CUP's CC councils."36

\section{Conclusion}

What is so extraordinary about this initiative is the significant campaign by Turkish authorities to promote Lewy's book by mobilizing their manifold resources, including worldwide diplomatic posts. Universities, public libraries, the media, and even political leaders are being targeted. Furthermore, Lewy has been and continues to be exalted in Ankara, where he has been invited and showered with special honors as a star. For an author who seems so firmly committed to joining his Turkish supporters in denying the genocidal fate of the Armenians, there will always be scope to raise questions about "convincing" and irrefutable "evidence" (e.g., 80-82, 87, 88), thereby casting doubt on the full measure of the utmost secrecy of the CUP's genocidal scheme and the details of its execution. Rhetoric, in all its grim shallowness, is pitted here against the overwhelming physical evidence of a crime of vast proportions. This shallowness is even more acutely evident in the list of countless factual errors that further degrades the volume under review. ${ }^{37}$

In an essay dealing with the issue of partisan scholarship, the late Terrence des Pres deplores the subservience of a growing number of academics to the lures and rewards of "power" at the expense of "the integrity of knowledge." He wonders whether the deliberate misuse of the maxim "there are two sides to every issue" has not reduced it to a "gimmick" to undermine and distort rather than to "foster truth." He goes on to write,

We are now told no [Armenian] genocide took place but only a vague unfortunate mishap determined by imponderables like time and change, the hazards of war, uncertain demographics. There is a commonsense sound to the Turkish proposal... [However,] Turkey's denial of the Armenian disaster is backed by something larger than mere doubt....38

In a subsequent essay, Des Pres scorns the "increasing attempts to suborn the academy... The issue, then, is whether or not we wish to be menials, for at the very least scholars who spend their resources defending the honor of nation-states serve something other than truth.",39

What kind of scholarship should we expect from our historians when a mountain of evidence, first-hand reports, and documented testimonials presents undeniable facts? In Yerevan on 1 October 2006, Jacques Chirac declared, "By recognizing the genocide of Jews, Germany did not lose its greatness and self-confidence. On the contrary, a country and nation develops by admitting the mistakes made in the past." 40 Denying the Armenian Genocide when so much evidence exists is both counterproductive and, ultimately, cowardly. Guenter Lewy may dispute it, but he has failed, in this volume, to make his case. His failure is largely due to his goal-oriented selectivity, which, ultimately, raises a far more important question: Can Turkey aspire to democracy 
when members of its elite and their acolytes fail to face the errors and crimes of their past?

\section{Notes}

1. Angelique Chrisafis, “Turkey Warns France Over Armenian Genocide Bill,” The Guardian, 11 October 2006, http://www.guardian.co.uk/print/ 0,,329597736-111247,00.html (accessed 7 May 2007). See also Natalie Nougayrède, "Jacques Chirac lie l'adhésion turque à la reconnaissance du génocide arménien," Le Monde, 3 October 2006, 6.

2. Professor Lewy is a well-known historian, although his scholarship is primarily concentrated on the United States and Europe not on Armenia, the Armenian Genocide, Turkey, the Caucasus, the Muslim world, or the Middle East. He has taught at Columbia University, Smith College, and the University of Massachusetts and currently lives in Washington, DC; he is a frequent contributor to Commentary. Over the years, Lewy has published several books, including America in Vietnam (1978); Peace and Revolution: The Moral Crisis of American Pacifism (1988); The Cause That Failed: Communism in American Political Life (1990); Why America Needs Religion: Secular Modernity and Its Discontents (1996); The Catholic Church and Nazi Germany (2000); The Nazi Persecution of the Gypsies (2001); and, most recently, The Armenian Massacres in Ottoman Turkey: A Disputed Genocide (2005). Save for his last contribution, all of his previous books dealt with either the United States or Europe. In fact, his 1978 study on Vietnam was so controversial-because it alleged behavior on the part of United States Marines that was later contested - that US government officials and other historians questioned it. "In November 2004, Lewy published an essay charging University of Colorado historian Ward Churchill with misrepresenting his sources," claiming "that Churchill's assertion that the U.S. Army intentionally spread smallpox among American Indians by distributing infected blankets in 1837 [wa]s false." Guenter Lewy, "Were American Indians the Victims of Genocide?" Commentary, September 2004, 55-63, 56. Importantly, Professor Lewy has concluded that the massacres of American Indians did not constitute genocide, a denial that came before his latest allegations regarding Armenians. Before the publication of his latest volume, Lewy published "The First Genocide of the Twentieth Century?" Commentary, December 2005, 47-52, and "Revisiting the Armenian Genocide," Middle East Quarterly 12, no. 4 (Fall 2005), http://www.meforum.org/article/748 (accessed 7 May 2007; also available in Turkish, http://www.meforum.org/article/880).

3. Selcuk Gultasli, "No Evidence of Ottoman Intent to Destroy Armenian Community," Zaman Online, 24 April 2006, http://www.zaman.com/?bl=interviews\&alt=\&hn=32399 (accessed 7 May 2007).

4. Unlike Lewy, who acknowledges not knowing either Turkish or, for that matter, Armenian, Armenian scholars who research and write on this topic actually read and understand whatever is available in Turkish, as well as in a slew of Western languages. To simply assume otherwise is an error that should no longer be made, especially by authors who lack any proficiency in the languages in question.

5. George Abel Schreiner, The Craft Sinister: A Diplomatic-Political History of the Great War and Its Causes (New York: G. Albert Geyer, 1920), 124-25.

6. George Abel Schreiner, From Berlin to Bagdad: Behind the Scenes in the Near East (New York: Harper \& Brothers, 1918), 332.

7. Ibid., 207.

8. "Kein einheitlicher Aufstand." Leopold Gustav Alexander von Hoesch, "Aufzeichnung über die armenische Frage," n.d. [1916], Politisches Archiv des Auswärtigen Amtes (Berlin), T-183/44/A25749, fiches 7153-54, $1^{4}$. Unless otherwise indicated, all translations into English are my own.

9. "Die Deportationen vor sich sahen und deshalb vorzogen sich zur Wehr zu setzen, als einem ungewissen Schicksal zu ergeben": ibid., 42. It should be noted in this connection that, playing with words, Lewy misrepresents Vahakn Dadrian's views on the Van uprising (94) 
alleging that Dadrian misquotes the German chief of staff of the Ottoman Third Army, Felix Guse. Guse was, at best, ambivalent about such a general uprising. He spoke of "unrest" in some places, of "fights" in other areas, and wrote of general tranquility throughout. He then raised the rhetorical question: "What should we do? Wait to see if the Armenian would be so noble as to refrain from hostile acts?" See Felix Guse,

"Der Armenenieraufstand 1915 und seine Folgen," Wissen und Wehr 10 (1925), 615. It may be useful to note that Dadrian differentiates the Van uprising from "a general uprising of the Armenians."

10. "Den Insurgenten wird man freilich zugute halten müssen." Von Hoesch, 52.

11. Ibid., 52.

12. Interview with Salahattin Güngör, in Resimli Tareh, July 1953, 2445. See also Midhat Sükrü Bleda, Imparatarlugun Çöküsü (Istanbul: Remzi, 1979), 61.

13. Rafael de Nogales, Four Years Beneath the Crescent (New York: C. Scribner's Sons, 1926), 60.

14. Ibrahim Arvas, Tarihi Hakikatlar [Historical Truths] (Ankara: Resimli Posta, 1964), 6.

15. Meclis-i Mebusan Zabut Ceridesi [Transcripts of the Proceedings of the Chamber of Deputies], archives, 11 December 1918, 300.

16. Robert Fisk, "Let Me Denounce Genocide from the Dock," The Independent, 14 October 2006, http://news.independent.co.uk/world/fisk/article1870851.ece (accessed 7 May 2007).

See also Taner Akçam, A Shameful Act: The Armenian Genocide and the Question of Turkish Responsibility (New York: Metropolitan Books, 2006), 152. For an equally devastating indictment of many such distortions, see Elizabeth Kolbert, "Books: Dead Reckoning-The Armenian Genocide and the Politics of Silence," The New Yorker, 6 November 2006, 120-24.

17. Ali Fuad Erden, Birinci Dünya Harbinde Suriye Hatıralart [Memoirs of World War I in Syria] (Istanbul: Halk, 1954), 122.

18. Ahmed Refik Altinay, Iki Komite, Iki Kital [Two Committees, Two Massacres] (Istanbul: Ottoman Script, 1919; reprint, Ankara: Kebiçek, 1994), 34.

19. Taner Akçam, Türk Ulusal Kimligi ve Ermeni Sorunu (Istanbul: Dünya Yayınlari, 1991), 106.

20. Johannes Lepsius, Deutschland und Armenien 1914-1918 (Berlin: Temple Verlag, 1919), 103.

21. For the text of the article see Christine von den Wijingaert, Guy Stessewns, and Liesbeth Janssens, eds., International Criminal Law: A Collection of International and European Instruments, 3rd ed. (Leiden: Martinus Nijhoff, 2005), 39.

22. Takvîm-i Vekâyi [Official Gazette of the Turkish Military Tribunal] 3540 (5 May 1919), $10-14$.

23. George Young, Corps de Droit Ottoman, vol. 7 (Oxford: Oxford University Press, 1906), 226; John Bucknill and Haig Utidjian, The Imperial Ottoman Penal Code (Nicosia: Oxford University Press, 1913), xiv.

24. A. Billiotti and Ahmed Sedad, Législation ottoman depuis le rétablissement de la constitution, vol. 1 (Paris: Jouve et Cie., 1912), 194-95, 482-83. The Temporary Law on the State of Siege was first promulgated on 2 October 1877, then revised on 20 June 1909 and again on 1 September 1910.

25. Yusuf Hikmet Bayur, Türk Inkilapi Tarihi, vol. 3, pt. 1 (Ankara: Türk Tarih Kurumu, 1983), 484.

26. Archives of the Armenian Patriarchate at Jerusalem, ser. 17, file H, no. 176; Takvîm-i Vekâyi, No. 3540 (5 May 1919). Text appended to the Annex contains the specific documents lodged with the key indictment.

27. Ergun Hiçyilmaz, Belgelerle Teşkiläti Mahsusa [The Special Organization in Light of the Documents] (Istanbul: Ünsal, 1979), 102.

28. Suat Parlar, Osmanlıdan Günümüze Gizli Devlet [The Secretive State: From the Ottoman Era to Our Days] (Istanbul: Spartakus, 1996), 346. 
29. Ihsan Bïrinci, "Cemiyet ve Çeteler [The CUP and the Brigands]," Hayat va Tarih 2:9 (1979): 99-105, 102.

30. Altinay, Iki Komite, 27.

31. Galib Vardar, Ittihad ve Terakki Içinde Dönenler [The Inside Story of the CUP] (Istanbul: Inkilap Kitabevi, 1960), 244-46.

32. Tarik Zafer Tunaya, Türkiyede Siyasal Partiler [Political Parties in Turkey], vol. 3 (Istanbul: Hürriyet Vakfi Publishers, 1989), 278, 282.

33. Sevket Süreyya Aydemir, Makedonya'dan Ortaasya'ya Enver Paşa, vol. 3 (Istanbul: Remzi Kitabevi, 1981), 489.

34. Celal Bayar, Ben de Yazdım [I Wrote Also], vol. 5 (Istanbul: Baha Matbaasi, 1966), 1573.

35. Doğan Avcıŏlu, Milli Kurtuluş Tarihi: 1838 den 1995e [History of National Liberation from 1838 to 1995], vol. 3 (Istanbul: Istanbul Publishing House, 1974), 1114.

36. Ibid., 1135.

37. The following are illustrative: (1) Liparit was not a German missionary, as asserted on page 65, but an Armenian intellectual. (2) Colonel Stange was part of the Third Turkish Army, not the Third Turkish Division(85). Reşit Akif Pasha was not a member of the cabinet but president of the State Council, a very different governmental organ (89). (3) Van's governor-general was not Cedvet but Cevdet Pasha (99). (4) The Treaty of Sèvres was signed on 10 August, not on 19 August (123). (5) The decree of deportation was issued on 13 May 1915 (old style), which would be 26 May (new style), not 23 May (186). (6) German General Bronsart was not commander-in-chief but chief of the general staff of the Turkish Armed Forces (229).

38. Terrence des Pres, "On Governing Narratives: The Turkish-Armenian Case," The Yale Review 75 (1986): 517-31, 518-19.

39. Terrence des Pres, "Introduction: Remembering Armenia," in The Armenian Genocide in Perspective, ed. Richard G. Hovannisian, 9-17 (New Brunswick, NJ: Transaction Publishers, 1987), 15.

40. Samvel Sargsian and Hasmik Hakobian, "French President Pays His First Visit to Armenia," Noyan Tapan Highlights, 9 October 2006, 1-2. 